\title{
Management of refractory cirrhotic ascites: challenges and solutions
}

This article was published in the following Dove Press journal: Hepatic Medicine: Evidence and Research

\section{Hiroshi Fukui \\ Hideto Kawaratani \\ Kosuke Kaji \\ Hiroaki Takaya \\ Hitoshi Yoshiji}

Department of Gastroenterology, Endocrinology and Metabolism, Nara Medical University, Nara, Japan

\section{Video abstract}

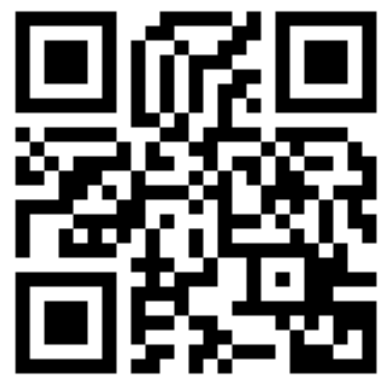

Point your SmartPhone at the code above. If you have a $Q R$ code reader the video abstract will appear. Or use: http://youtu.be/gvUxOA7Rsx4
Correspondence: Hiroshi Fukui Department of Gastroenterology, Endocrinology and Metabolism, Nara Medical University, 840 Shijo-Cho, Kashihara 634-8522, Nara, Japan

Tel +8174422305 I

Fax +8I 744247122

Email hfukui@naramed-u.ac.jp
Abstract: Among the various risky complications of liver cirrhosis, refractory ascites is associated with poor survival of cirrhotics and persistently worsens their quality of life (QOL). Major clinical guidelines worldwide define refractory ascites as ascites that cannot be managed by medical therapy either because of a lack of response to maximum doses of diuretics or because patients develop complications related to diuretic therapy that preclude the use of an effective dose of diuretics. Due to the difficulty in receiving a liver transplantation (LT), the ultimate solution for refractory ascites, most cirrhotic patients have selected the palliative therapy such as repeated serial paracentesis, transjugular intrahepatic portosystemic shunt, or peritoneovenous shunt to improve their QOL. During the past several decades, new interventions and methodologies, such as indwelling peritoneal catheter, peritoneal-urinary drainage, and cell-free and concentrated ascites reinfusion therapy, have been introduced. In addition, new medical treatments with vasoconstrictors or vasopressin V2 receptor antagonists have been proposed. Both the benefits and risks of these old and new modalities have been extensively studied in relation to the pathophysiological changes in ascites formation. Although the best solution for refractory ascites is to eliminate hepatic failure either by LT or by causal treatment, the selection of the best palliative therapy for individual patients is of utmost importance, aiming at achieving the longest possible, comfortable life. This review briefly summarizes the changing landscape of variable treatment modalities for cirrhotic patients with refractory ascites, aiming at clarifying their possibilities and limitations. Evolving issues with regard to the impact of gut-derived systemic and local infection on the clinical course of cirrhotic patients have paved the way for the development of a new gut microbiome-based therapeutics. Thus, it should be further investigated whether the early therapeutic approach to gut dysbiosis provides a better solution for the management of cirrhotic ascites.

Keywords: pathophysiology, nonselective beta-blockers, V2 receptor antagonists, large-volume paracentesis, peritoneovenous shunt, transjugular intrahepatic portosystemic shunt, antibiotics

\section{Introduction}

Patients with advanced liver cirrhosis tend to develop various risky complications, including gastroesophageal varices, ascites, hepatic encephalopathy (HE), and renal and cardiac disturbance as a consequence of portal hypertension, and hyperdynamic circulation and their hemodynamic and metabolic effects. ${ }^{1}$ Among others, refractory ascites is associated with poor survival and persistently worsens the quality of life (QOL) of cirrhotic patients. The International Ascites Club defines refractory ascites as ascites that cannot be managed by medical therapy either because of a lack of response 
to maximum doses of diuretics (spironolactone $400 \mathrm{mg} /$ day and furosemide $160 \mathrm{mg} /$ day) or because patients develop complications related to diuretic therapy that preclude the use of an effective dose of diuretics (Table 1A). ${ }^{2,3}$ The clinical guidelines of the European Association for the Study of the Liver (EASL) and the American Association for the Study of Liver Diseases (AASLD) have also adopted this definition, although the latter has simplified it to some degree. ${ }^{4,5}$ Refractory ascites is further subdivided into diuretic-resistant ascites (lack of response to maximum doses of diuretics) and diuretic-intractable ascites (inability to take an effective diuretic dosage due to diuretic-induced complications). ${ }^{2,4}$ These definitions have been acknowledged as the world standard for cirrhotic ascites since then. However, when attempting to find a scientific basis for the maximum doses of diuretics for intensive diuretic therapy, we should revisit the period before the start of evidence-based medicine. There is a possibility that the maximum doses may be influenced by the patients' profiles and conditions, that is, their races, statures, ages, and dietary habits. In fact, several authors have adopted different criteria of refractory ascites based on the diuretic doses of their standard treatment regimen, although some of them can be hardly considered as the maximal diuretic doses (Table 1B). ${ }^{6,7}$ In this review, we followed the definition of the International Ascites Club, laying aside these problems, in order to arouse comprehensive discussions across various studies worldwide. Although liver transplantation (LT) is undoubtedly the ultimate solution for refractory ascites in liver cirrhosis, most patients have to wait for a long period of time or even die before the operation because of absolute organ shortage. Therefore, various therapeutic strategies for refractory ascites, whether by large-volume paracentesis (LVP), transjugular intrahepatic portosystemic shunt (TIPS), or peritoneovenous shunt (PVS), should be mainly designated to improve QOL of cirrhotic patients. The remarkable progress in technology during the past few decades has gradually enabled patients with advanced cirrhosis to enjoy a better life without annoying symptoms and discomfort. This review briefly summarizes the evolving landscape of variable treatment modalities for cirrhotic patients with refractory ascites and introduces the most up-to-date challenges and solutions in this field.

Table I Definition of refractory ascites in international guidelines $(\mathbf{A})$ and criteria of refractory ascites used by authors from China and Japan (B)

\begin{tabular}{|c|c|}
\hline A & \\
\hline $\begin{array}{l}\text { EASL clinical practice } \\
\text { guideline }\end{array}$ & $\begin{array}{l}\text { Ascites that cannot be mobilized or the early recurrence of which (i.e., after therapeutic paracentesis) cannot be } \\
\text { satisfactorily prevented by medical therapy }\end{array}$ \\
\hline International Ascites Club² & $\begin{array}{l}\text { Diuretic-resistant ascites: Ascites that cannot be mobilized or the early recurrence of which cannot be prevented } \\
\text { because of a lack of response to sodium restriction and diuretic treatment } \\
\text { Diuretic-intractable ascites: Ascites that cannot be mobilized or the early recurrence of which cannot be prevented } \\
\text { because of the development of diuretic-induced complications that preclude the use of an effective diuretic dosage } \\
\text { I. Treatment duration: Patients must be on intensive diuretic therapy (spironolactone } 400 \mathrm{mg} / \text { day and furosemide } \\
160 \mathrm{mg} / \text { day) for at least I week and on a salt-restricted diet of }<90 \mathrm{mmol} / \text { day } \\
\text { 2. Lack of response: Mean weight loss of }<0.8 \mathrm{~kg} \text { over } 4 \text { days and urinary sodium output less than the sodium intake } \\
\text { 3. Early ascites recurrence: Reappearance of grade } 2 \text { or } 3 \text { ascites within } 4 \text { weeks of initial mobilization }\end{array}$ \\
\hline $\begin{array}{l}\text { AASLD clinical practice } \\
\text { guideline }^{5}\end{array}$ & $\begin{array}{l}\text { Refractory ascites is defined as fluid overload that } \mathrm{I} \text { ) is unresponsive to sodium-restricted diet and high-dose diuretic } \\
\text { treatment ( } 400 \mathrm{mg} / \text { day of spironolactone and } 160 \mathrm{mg} / \text { day of furosemide), or 2) recurs rapidly after therapeutic } \\
\text { paracentesis }\end{array}$ \\
\hline \multicolumn{2}{|l|}{ B } \\
\hline Zhang et $\mathrm{al}^{36}$ & $\begin{array}{l}\text { Ascites that cannot be satisfactorily controlled after a patient had either I) I week of sodium intake restrictions ( }<6 \\
\mathrm{~g} / \text { day), intermittent albumin infusion ( } 10-20 \mathrm{~g} \text { per treatment), and high doses of diuretics ( }>160 \mathrm{mg} / \text { day of furosemide } \\
\text { and } 200 \mathrm{mg} / \text { day of spironolactone), or } 2) 2 \text { weeks of therapeutic paracentesis ( } 3000-5000 \mathrm{~mL} \text { per treatment) }\end{array}$ \\
\hline Taki et al ${ }^{125}$ & $\begin{array}{l}\text { Defined either as a }<1.5 \mathrm{~kg} / \text { week weight loss while being treated with furosemide ( } 100 \mathrm{mg} / \text { day) and spironolactone } \\
\text { ( } 150 \mathrm{mg} / \text { day) or as a }<1.5 \mathrm{~kg} / \text { week weight loss due to the inability to use an effective dose of diuretics because of } \\
\text { development of diuretic-induced hyponatremia (sodium level }<125 \mathrm{mEq} / \mathrm{L} \text { ), hyperkalemia (potassium level }>5.5 \mathrm{mEq} / \mathrm{L} \text { ), } \\
\text { azotemia (doubling of serum creatinine or values }>1.5 \mathrm{mg} / \mathrm{dL} \text { ), or hepatic encephalopathy (greater than grade } 2 \text { as } \\
\text { defined by Parsons-Smith criteria) while on a dietary restriction of sodium } 5 \mathrm{~g} / \text { day as a minor modification }\end{array}$ \\
\hline Ohki et $\mathrm{al}^{6}$ & $\begin{array}{l}\text { Ascites detected by ultrasound under the treatment of a loop diuretic at a daily dose equivalent to } \geq 40 \mathrm{mg} / \text { day } \\
\text { furosemide and } \geq 25 \mathrm{mg} / \text { day spironolactone, a loop diuretic at a daily dose equivalent to } \geq 20 \mathrm{mg} / \text { day furosemide and } \\
\geq 50 \mathrm{mg} / \text { day spironolactone, or a loop diuretic alone at a daily dose equivalent to } \geq 60 \mathrm{mg} / \text { day furosemide }\end{array}$ \\
\hline$\overline{T \text { Tahara et al }{ }^{7}}$ & Ascites that had not been controlled by standard diuretics ( $\geq 20 \mathrm{mg} /$ day furosemide and/or $25 \mathrm{mg} /$ day spironolactone) \\
\hline
\end{tabular}

Abbreviations: AASLD, American Association for the Study of Liver Diseases; EASL, European Association for the Study of the Liver. 


\section{Background of refractory ascites}

Portal hypertension and splanchnic arterial vasodilation, both of which are closely related to gut-derived endotoxemia, constitute major factors in the development of ascites in liver cirrhosis. ${ }^{8,9}$ Three hypotheses, the underfilling theory, overflow theory, and peripheral arterial vasodilation theory, are considered as explanations for the variable pathophysiological changes in patients with advanced liver cirrhosis. ${ }^{10} \mathrm{In}$ our stepped care medical treatment for cirrhotic patients with ascites, the poor responders to diuretics were characterized by elevated basal plasma renin activity (PRA), norepinephrine (NE), and arginine vasopressin (AVP or antidiuretic hormone) levels, together with low basal creatinine clearance, urine volume, urinary $\mathrm{Na}$ excretion, and serum $\mathrm{Na}$ levels and high basal blood urea nitrogen levels. ${ }^{10,11}$ These results contrasted sharply with those in the early responders, who showed normal basal renal function, and serum $\mathrm{Na}$, PRA, NE, and AVP levels, and elevated basal plasma $\alpha$-human atrial natriuretic peptide (ANP) levels. ${ }^{10}$ These findings suggest that the poor responders are in the state of relative vascular underfilling compared with the early responders, who are in a state of overflowing. ${ }^{11}$ In the advanced stage of cirrhosis, splanchnic vasodilation causes marked arterial underfilling, which induces maximal activation of the renin-angiotensinaldosterone system (RAAS), the sympathetic nervous system (SNS), and AVP. Reduced renal perfusion and further $\mathrm{Na}$ and water retention with dilutional hyponatremia are natural consequences of cirrhosis in patients with refractory ascites. ${ }^{12}$

\section{Modification of drug therapy}

There have been several challenges in the pharmacotherapy of refractory ascites. All of these are based on certain aspects of the pathophysiological changes in ascites formation, which have sometimes represented conflicting results. Thus, we need additional well-designed prospective studies to modify the current strategy of pharmacotherapy, thereby improving its effectiveness.

\section{Vasoconstrictors}

Midodrine, a potent peripherally acting $\alpha$-adrenergic receptor agonist, increases effective arterial blood volume by splanchnic vasoconstriction and improves renal perfusion and the glomerular filtration rate (GFR) ${ }^{13}$ Midodrine can be added to diuretics for elevating blood pressure (BP) of cirrhotic patients and restoring their sensitivity to diuretics. ${ }^{14}$ Midodrine alone ${ }^{8}$ or along with octreotide and albumin ${ }^{15}$ has been shown to enable better control of ascites both in short-term ${ }^{15}$ and long-term ${ }^{8}$ pilot trials in cirrhotic patients with refractory or recurrent ascites. ${ }^{13}$ Oral midodrine $7.5 \mathrm{mg}$ thrice daily has been reported to prolong patient survival. ${ }^{8}$ The latest AASLD practice guideline recommends it as a simple medical treatment option preceding LVP or TIPS.

On the other hand, clonidine, an $\alpha 2$-adrenergic receptor agonist, demonstrates sympathoinhibitory effects and suppresses RAAS in patients with liver cirrhosis. ${ }^{13}$ Clonidine augments the effect of spironolactone facilitating an earlier diuretic response with smaller diuretic requirements and fewer complications. ${ }^{16}$ Yang et al ${ }^{17}$ evaluated the effects of diuretics (furosemide+spironolactone) and their combination with clonidine on refractory ascites, and they found a $60 \%$ response rate after 3 months of clonidine-diuretic combination therapy. A higher percentage of decrease in plasma NE, renin, and aldosterone levels from baseline was observed among clonidine responders. ${ }^{17}$ Clonidine may thus become a promising additional pharmacologic tool to augment the effect of diuretics on refractory ascites, wherein the RAAS and SNS are highly activated. Singh et $\mathrm{al}^{13}$ investigated the effects of midodrine $(7.5 \mathrm{mg} / 8 \mathrm{~h})$, clonidine $(0.1 \mathrm{mg} / 12 \mathrm{~h})$, and their combination with standard diuretic therapy (sodium restriction, diuretics, and repeated LVP as needed) on systemic hemodynamics, renal function, and control of ascites in cirrhotic patients with refractory or recurrent ascites. They found that all three were superior to diuretic therapy alone, but the effect of combination therapy was not greater than that of midodrine or clonidine.

The vasopressin $\mathrm{V} 1$ receptor agonist terlipressin was shown to improve renal function and induce natriuresis in patients with cirrhosis and ascites including those with refractory ascites. ${ }^{18}$ Terlipressin was further reported to increase water excretion during a water load test in nonazotemic cirrhotic patients without hyponatremia. ${ }^{19}$ A prospective study ${ }^{20}$ has reported the synergistic effect of terlipressin and standard diuretic therapy (maximum diuretics plus albumin) in patients with refractory ascites. Studies have indicated that the administration of arterial vasoconstrictors may influence the prognosis of patients with refractory ascites.

\section{Nonselective $\beta$-blockers}

In a prospective observational study by Sersté et al, ${ }^{21}$ it was first reported that the administration of nonselective $\beta$-blockers (NSBBs) to critically decompensated patients, especially those with refractory ascites, may be dangerous, mainly due to worsening of systemic hemodynamics and increasing risks of renal failure, severe infection, and mortality. ${ }^{22}$ In the Cox multivariate regression analysis, the independent predictors for mortality were the presence of 
hepatocellular carcinoma, NSBB therapy, Child-Pugh class $\mathrm{C}$, and refractory ascites associated with hyponatremia and/ or renal failure. ${ }^{21}$ These results have led to the formulation of a "window hypothesis" on the indications of NSBB in cirrhotic patients, which claims that cirrhotic patients benefit from the use of NSBBs within a narrow window from the appearance of risky esophageal varices up to the development of refractory ascites or other severe complications, such as spontaneous bacterial peritonitis (SBP) and hepatorenal syndrome (HRS). ${ }^{23,24}$ In line with this, the latest AASLD guidelines propose that consideration should be given to discontinuing or not initiating NSBB in patients with refractory ascites. ${ }^{5}$ Serste et $\mathrm{al}^{21}$ further considered that the prognosis of diuretic-intractable refractory ascites may be worse than the diuretic-resistant refractory ascites because the former is more frequently associated with hyponatremia and renal impairment.

On the contrary, recent studies ${ }^{25-27}$ have reported that NSBBs do not impair the survival of patients with cirrhosis and ascites (including those with refractory ascites), especially if these NSBBs are discontinued when the mean arterial pressure (MAP) decreases and are reinitiated once the MAP recovers. ${ }^{27}$ Propranolol (120 mg/day) has been proven to ameliorate gastroduodenal/intestinal permeability and to reduce bacterial translocation (BT) which are partially unrelated to their hemodynamic effects on portal pressure. ${ }^{28}$ A comprehensive review by Blasco-Algora et $\mathrm{al}^{29}$ summarizes these studies and proposes the clinical situations in which NSBBs should be withheld as follows: Child-Pugh-Turcotte class C or Model for End-stage Liver Disease (MELD) score $\geq 25$, and 1) diuretic-intractable refractory ascites, 2) cardiac index $\leq 1.5 \mathrm{~L} / \mathrm{min} / \mathrm{m}^{2}, 3$ ) systolic $\mathrm{BP} \leq 90 \mathrm{mmHg}$ (either spontaneous or NSBB-induced), and 4) within 6 months of first episode of SBP, as long as hemodynamic deterioration is sustained (e.g., BP $\leq 90 \mathrm{mmHg}$ and/or cardiac index $\leq 1.5 \mathrm{~L} / \mathrm{min} / \mathrm{m}^{2}$ ). The authors further recommended that the maximal dose of propranolol should be set at 40-80 mg/day if patients' MELD score is $18-24$ because a high NSBB dose (160 mg/day) is associated with more harmful effects to the systemic circulation and less tolerance. ${ }^{21}$ Moctezuma-Velazquez et $\mathrm{al}^{30}$ have recently summarized practical recommendations proposing that NSBBs should be used cautiously with close monitoring of BP, serum sodium, and creatinine, and should be reduced or discontinued if a patient with refractory ascites develops systolic BP $<90 \mathrm{mmHg}$, hyponatremia $<130 \mathrm{mEq} / \mathrm{L}$, or acute kidney injury (AKI).

Taken together, it should be noted that NSBBs are not indicated for the treatment of refractory ascites. Eradication of risky varices by prophylactic endoscopic sclerotherapy and interventional radiology may alleviate the burden of continuous NSBB administration for patients with refractory ascites.

\section{V2 receptor antagonists}

An impaired renal water handling, leading to the inability to excrete a water load and hyponatremia, represents a common finding in advanced liver cirrhosis. ${ }^{31}$ Refractory ascites often involves hyponatremia, which indicates more intense water retention. ${ }^{32}$ Free water clearance, an index of water excretion, is known to be markedly decreased in these patients. Given the central role of vasopressin in limiting renal water excretion in cirrhotic patients, vasopressin V2 receptor antagonists are considered as a rational approach for cirrhotic patients with refractory ascites and dilutional hyponatremia. In line with this, the effects of several V2 receptor antagonists on ascites and hyponatremia have been evaluated. ${ }^{10}$ Among them, satavaptan was reported to be effective for controlling ascites and hyponatremia in cirrhotic patients under diuretic treatment (spironolactone $100 \mathrm{mg}$ /day). On one hand, longterm large-scale double-blind randomized controlled trials (RCTs) finally revealed that satavaptan, alone or in combination with diuretics (spironolactone $100 \mathrm{mg} /$ day), is not effective in preventing the recurrence of ascites after LVP. ${ }^{33}$ When satavaptan was administered in combination with diuretics to prevent ascites recurrence after LVP, a higher rate of all-cause mortality, mostly associated with known complications of cirrhosis, was recorded during the 52 weeks of follow-up. ${ }^{33}$ These limited efficacy and safety concerns resulted in the premature discontinuation of the trial and withdrawal of the drug by the pharmaceutical company. On the other hand, the effect of another V2 receptor antagonist, tolvaptan, has been explored in combination with lower doses of diuretics in cirrhotic patients with ascites. Tolvaptan $(7.5-30 \mathrm{mg} /$ day for 7 days) showed add-on effects to conventional diuretics on ascites in the multicenter RCTs for the poor responders to the standard diuretic therapy (furosemide $\geq 40 \mathrm{mg}$ /day and spironolactone $\geq 25 \mathrm{mg} /$ day; or furosemide $\geq 20 \mathrm{mg} /$ day and spironolactone $\geq 50 \mathrm{mg} /$ day). ${ }^{34}$ Its proper dose was settled as $3.75-7.5 \mathrm{mg} /$ day for Japanese cirrhotic patients. ${ }^{35}$ From a theoretical perspective, the combination of vaptans with diuretics may be useful in patients with refractory ascites, reducing the frequency of LVP. ${ }^{12}$ This hypothesis, however, has not been validated with large-scale RCTs. A study by Zhang et $\mathrm{al}^{36}$ reported that the combination of $15 \mathrm{mg} /$ day tolvaptan with diuretics effectively increased the urine output in $89.7 \%$ of 39 patients with refractory ascites. This was the only report with regard to its effect on definite refractory ascites, which 
was not controlled after either 1 week of sodium restriction, albumin infusion, and high doses of diuretics ( $>160 \mathrm{mg} /$ day of furosemide and $200 \mathrm{mg}$ /day of spironolactone) or 2 weeks of LVP. In other studies, ${ }^{6,7,37}$ it is not clear whether the patients were given the highest possible dose of diuretics prior to the diagnosis of refractory ascites.

\section{Challenges in intervention therapy}

Although LT is the only curative option for refractory ascites, ${ }^{38}$ the difficulty of receiving successful transplantation has paved the way for the development of various alternative interventional approaches. We have summarized the indications and contraindications of these therapies with their pros and cons in Table 2. There have been various challenges with regard to the improvement of these modalities in the past decade.

\section{LVP}

Both the EASL and AASLD guidelines ${ }^{4,5}$ indicate that the first-line treatment for patients with refractory ascites is LVP associated with the administration of intravenous albumin. ${ }^{3}$ The last AASLD guideline further recommends discontinuing $\beta$-blockers and adding midodrine prior to serial therapeutic paracentesis. ${ }^{5}$ LVP is known to achieve marked reduction of intra-abdominal, intrathoracic, and pulmonary pressures, ${ }^{39}$ as well as rapid fall of portal pressure ${ }^{40}$ without

Table 2 Comparisons of various treatments for refractory ascites: review of available information

\begin{tabular}{|c|c|c|c|c|}
\hline & Indications & Contraindications & Pros & Cons \\
\hline Repeated LVP & $\begin{array}{l}\text { - First-line treatment for } \\
\text { tense ascites } \\
\text { - Respiratory compromise } \\
\text { and abdominal pain or } \\
\text { pressure secondary to } \\
\text { tense ascites } \\
\text { - Refractory ascites } \\
\text { unresponsive to routine } \\
\text { medical therapy (after } \\
\text { discontinuing } \beta \text {-blockers } \\
\text { and adding midodrine }{ }^{5} \text { ) }\end{array}$ & $\begin{array}{l}\text { - Acute abdomen that requires } \\
\text { surgery } \\
\text { - Severe thrombocytopenia (platelet } \\
\left.\text { count }<20 \times 10^{9} / \mathrm{L}\right) \\
\text { - Coagulopathy (INR }>2.0 \text { ) } \\
\text { - Multiple abdominal scars } \\
\text { - Infection of peritoneal cavity or } \\
\text { - Intra-abdominal adhesions } \\
\text { - Uncontrollable HE }\end{array}$ & $\begin{array}{l}\text { - Fast, effective, and safe } \\
\text { - Achieves a marked } \\
\text { reduction of intra- } \\
\text { abdominal, intrathoracic, } \\
\text { and pulmonary pressures } \\
\text { - A rapid fall of portal } \\
\text { pressure without } \\
\text { any renal and hepatic } \\
\text { dysfunction }\end{array}$ & $\begin{array}{l}\text { - Carries a risk of post- } \\
\text { paracentesis circulatory } \\
\text { dysfunction that causes } \\
\text { reduced long-term } \\
\text { survival }\end{array}$ \\
\hline $\begin{array}{l}\text { Indwelling } \\
\text { peritoneal } \\
\text { catheter } \\
\text { (PleurX' }{ }^{\mathrm{TM}} \\
\text { catheter) }\end{array}$ & $\begin{array}{l}\text { - Refractory ascites } \\
\text { unresponsive to routine } \\
\text { medical therapy } \\
\text { - Still symptomatic despite } \\
\text { bimonthly LVP and were } \\
\text { not candidates for TIPS or } \\
\text { PVS }\end{array}$ & $\begin{array}{l}\text { - Acute abdomen that requires } \\
\text { surgery } \\
\text { - Multi-loculated peritoneal cavity } \\
\text { - Severe thrombocytopenia (platelet } \\
\left.\text { count }<20 \times 10^{9} / \mathrm{L}\right) \\
\text { - Coagulopathy }(\mathrm{INR}>2.0 \text { ) } \\
\text { - Infection of peritoneal cavity or } \\
\text { - abdominal wall } \\
\text { - Untra-abdominal adhesions } \\
\end{array}$ & $\begin{array}{l}\text { - Reduce the incidence } \\
\text { of post-paracentesis } \\
\text { circulatory dysfunction by } \\
\text { enabling more frequent } \\
\text { but less extensive } \\
\text { drainages }\end{array}$ & $\begin{array}{l}\text { - High incidence of } \\
\text { infection for a long- } \\
\text { term drainage }\end{array}$ \\
\hline \multirow[t]{4}{*}{ CART } & $\begin{array}{l}\text { - Refractory ascites } \\
\text { unresponsive to routine } \\
\text { medical therapy }\end{array}$ & - Ascites infection such as SBP & $\begin{array}{l}\text { - Safe and effective just like } \\
\text { LVP with albumin infusion }\end{array}$ & $\begin{array}{l}\text { - High costs of the } \\
\text { instruments }\end{array}$ \\
\hline & & - High level of endotoxin in ascites & $\begin{array}{l}\text { Prevents prerenal failure } \\
\text { and hypoalbuminemia } \\
\text { caused by frequent LVP }\end{array}$ & - Frequent fever and chill \\
\hline & & - Bloody ascites & $\begin{array}{l}\text { - Improves abdominal } \\
\text { distension and anorexia }\end{array}$ & $\begin{array}{l}\text { - Occasional allergic } \\
\text { reactions }\end{array}$ \\
\hline & & $\begin{array}{l}\text { - Serum total bilirubin }>85.5 \mu \mathrm{mol} / \mathrm{L} \\
(>5 \mathrm{mg} / \mathrm{dL}) \\
\text { - Uncontrollable portal } \\
\text { hypertension-related } \\
\text { gastrointestinal bleeding } \\
\text { - Uncontrollable HE }\end{array}$ & $\begin{array}{l}\text { - Reduces albumin } \\
\text { transfusion }\end{array}$ & \\
\hline
\end{tabular}


Table 2 (Continued)

\begin{tabular}{|c|c|c|c|c|}
\hline & Indications & Contraindications & Pros & Cons \\
\hline \multirow[t]{2}{*}{$\begin{array}{l}\text { Peritoneal- } \\
\text { urinary } \\
\text { drainage } \\
\text { (alfapump } \\
\text { system) }\end{array}$} & $\begin{array}{l}\text { - Refractory ascites } \\
\text { unresponsive to routine } \\
\text { medical therapy }\end{array}$ & $\begin{array}{l}\text { - Active systemic or local infections, } \\
\text { such as SBP and urinary tract } \\
\text { infection }\end{array}$ & $\begin{array}{l}\text { - Effective for reducing the } \\
\text { need for paracentesis } \\
\text { (>50\% over } 6 \text { months) } \\
\text { and improving QOL }\end{array}$ & $\begin{array}{l}\text { - Frequent device and } \\
\text { procedure-related } \\
\text { adverse events }\end{array}$ \\
\hline & $\begin{array}{l}\text { - Unable to tolerate frequent } \\
\text { LVP (patients requiring } \\
\text { more than two LVP per } \\
\text { month) }\end{array}$ & $\begin{array}{l}\text { - Extensive ascites loculation } \\
\text { - Obstructive uropathy } \\
\text { - Contraindications for general } \\
\text { anesthesia } \\
\text { - Uncontrollable portal } \\
\text { hypertension-related } \\
\text { gastrointestinal bleeding } \\
\text { - Uncontrollable HE }\end{array}$ & $\begin{array}{l}\text { - Improves nutritional } \\
\text { status compared with LVP }\end{array}$ & $\begin{array}{l}\text { - Associated with } \\
\text { activation of } \\
\text { endogenous } \\
\text { vasoconstrictor systems } \\
\text { and impairment of } \\
\text { kidney function }\end{array}$ \\
\hline \multirow[t]{4}{*}{ PVS } & $\begin{array}{l}\text { - Diuretic-resistant patients } \\
\text { who are not candidates for } \\
\text { LT or TIPS, and who are } \\
\text { not candidates for serial } \\
\text { paracenteses (multiple } \\
\text { abdominal scars, etc.) }\end{array}$ & - Patients with HRS & $\begin{array}{l}\text { - Improves GFR and } \\
\text { provides palliation in } \\
83 \% \text { of patients with } \\
\text { intractable ascites waiting } \\
\text { LT without severe side } \\
\text { effects }\end{array}$ & - Poor long-term patency \\
\hline & $\begin{array}{l}\text { - Symptomatic ascites } \\
\text { following a TIPS revision }\end{array}$ & $\begin{array}{l}\text { Serum total bilirubin level } \\
>119.7 \mu \mathrm{mol} / \mathrm{L}(>7 \mathrm{mg} / \mathrm{dL})\end{array}$ & $\begin{array}{l}\text { - Controls ascites sooner } \\
\text { than TIPS }\end{array}$ & $\begin{array}{l}\text { - Excessive complications } \\
\text { (DIC, cardiac failure, } \\
\text { sepsis, etc.) }\end{array}$ \\
\hline & & $\begin{array}{l}\text { - Uncorrectable coagulopathy } \\
\text { (INR > 2.2) }\end{array}$ & $\begin{array}{l}\text { Prolongs the time to the } \\
\text { recurrence of ascites } \\
\text { compared with diuretic } \\
\text { treatment and LVP with } \\
\text { albumin infusion }\end{array}$ & $\begin{array}{l}\text { - No survival advantage } \\
\text { compared with medical } \\
\text { therapy }\end{array}$ \\
\hline & & $\begin{array}{l}\text { - Liver cirrhosis with HCC and } \\
\text { those with prolonged PT } \\
\text { - End-stage renal failure } \\
\text { - Severe heart failure } \\
\text { - Sepsis } \\
\text { - SBP or uncontrollable infection } \\
\text { - Septation of the peritoneal cavity } \\
\text { - Uncontrollable portal } \\
\text { hypertension-related } \\
\text { gastrointestinal bleeding } \\
\text { - Uncontrollable HE }\end{array}$ & $\begin{array}{l}\text { - Reduces postoperative } \\
\text { acute renal failure } \\
\text { compared with LVP and } \\
\text { albumin infusion }\end{array}$ & \\
\hline \multirow[t]{4}{*}{ TIPS } & $\begin{array}{l}\text { - Selected cirrhotic patients } \\
\text { with refractory ascites who } \\
\text { require more than two to } \\
\text { three LVP per month }\end{array}$ & Absolute contraindications & $\begin{array}{l}\text { - Reduces recurrence of } \\
\text { tense ascites compared } \\
\text { with LVP }\end{array}$ & - Induces HE \\
\hline & $\begin{array}{l}\text { - A bridge to liver } \\
\text { transplantation, especially } \\
\text { in patients with refractory } \\
\text { ascites and HRS }\end{array}$ & $\begin{array}{l}\text { - CHF (particularly right-sided heart } \\
\text { failure) }\end{array}$ & $\begin{array}{l}\text { - Improves renal function } \\
\text { especially in participants } \\
\text { with baseline estimated } \\
\text { GFRs }<60 \mathrm{~mL} / \mathrm{min} / 1.73 \mathrm{~m}^{2}\end{array}$ & $\begin{array}{l}\text { - Frequent shunt } \\
\text { dysfunction }\end{array}$ \\
\hline & & - Tricuspid regurgitation & $\begin{array}{l}\text { - Improves renal perfusion } \\
\text { and sodium excretion, } \\
\text { controls ascites, and } \\
\text { reverses HRS* }\end{array}$ & $\begin{array}{l}\text { - Associated with } \\
\text { increased mortality in } \\
\text { patients with severe } \\
\text { liver dysfunction }\end{array}$ \\
\hline & & $\begin{array}{l}\text { - Severe pulmonary hypertension } \\
\text { (mean pulmonary pressure } \\
>45 \mathrm{mmHg} \text { ) }\end{array}$ & $\begin{array}{l}\text { - Improves the LT-free } \\
\text { survival of patients, } \\
\text { compared with LVP* }\end{array}$ & $\begin{array}{l}\text { - Possible induction of } \\
\text { early liver failure in } \\
\text { cirrhotics with MELD } \\
\text { score of II or } 12 \text { and } \\
\text { low hemoglobin and } \\
\text { platelet count }\end{array}$ \\
\hline
\end{tabular}


Table 2 (Continued)

\begin{tabular}{|c|c|c|c|}
\hline Indications & Contraindications & Pros & Cons \\
\hline & $\begin{array}{l}\text { - Advanced liver failure (serum total } \\
\text { bilirubin }>85.5 \mu \mathrm{mol} / \mathrm{L} \text { ) }\end{array}$ & $\begin{array}{l}\text { - Corrects vascular } \\
\text { dysfunction and enhances } \\
\text { the benefits of NSBB }\end{array}$ & $\begin{array}{l}\text { - Induces long-term } \\
\text { cardiovascular changes, } \\
\text { including cardiac volume } \\
\text { overload }\end{array}$ \\
\hline & - Multiple hepatic cysts & $\begin{array}{l}\text { - Decreases the risk of } \\
\text { HRS }\end{array}$ & $\begin{array}{l}\text { - Increases pulmonary } \\
\text { hypertension }\end{array}$ \\
\hline & $\begin{array}{l}\text { - Uncontrolled systemic infection or } \\
\text { biliary obstruction }\end{array}$ & $\begin{array}{l}\text { - Economically } \\
\text { advantageous due to } \\
\text { less requirement for } \\
\text { paracentesis }\end{array}$ & \\
\hline & Relative contraindications & - Improves body & \\
\hline & - Obstruction of all hepatic veins & composition (fat-free & \\
\hline & - Complete portal vein thrombosis & mass, fluid-free body & \\
\hline & $\begin{array}{l}\text { - Hepatocellular carcinoma } \\
\text { (especially centrally located) }\end{array}$ & weight) & \\
\hline & - Severe coagulopathy (INR >5) & & \\
\hline & - Thrombocytopenia $\left(<20 \times 10^{9} / \mathrm{L}\right)$ & & \\
\hline & - Moderate pulmonary hypertension & & \\
\hline & $\begin{array}{l}\text { - Recurrent or persistent severe } \\
\text { spontaneous HE }\end{array}$ & & \\
\hline & - Liver failure (serum total bilirubin & & \\
\hline & $>5 \mathrm{I} .3 \mu \mathrm{mol} / \mathrm{L}$, Child-Pugh & & \\
\hline & score $>12)$ & & \\
\hline & - Cardiac dysfunction (ejection & & \\
\hline & fraction $<60 \%$ ) & & \\
\hline & - Cardiac diastolic dysfunction & & \\
\hline & - Advanced age (e.g., $>69$ years) & & \\
\hline
\end{tabular}

Note: *Results by covered TIPS stent.

Abbreviations: CART, cell-free and concentrated ascites reinfusion therapy; CHF, congestive heart failure; DIC, disseminated intravascular coagulation; GFR, glomerular filtration rate; HCC, hepatocellular carcinoma; HE, hepatic encephalopathy, HRS, hepatorenal syndrome; INR, international normalized ratio; LT, liver transplantation; LVP, large-volume paracentesis; MELD, Model for End-stage Liver Disease; NSBB, nonselective $\beta$-blocker; PT, prothrombin time; PVS, peritoneovenous shunt; QOL, quality of life; SBP, spontaneous bacterial peritonitis; TIPS, transjugular intrahepatic portosystemic shunt.

any renal and hepatic dysfunction. ${ }^{41}$ Paracentesis-induced circulatory dysfunction (PICD), defined as an increase in PRA by $>50 \%$ of the pretreatment value to a level of $>4 \mathrm{ng} / \mathrm{mL}$ per hour on the sixth day after paracentesis, has been associated with a rapid recurrence of ascites, renal failure, and shorter survival. ${ }^{42,43}$

A meta-analysis reported that albumin infusion reduced the morbidity (incidence of PICD and hyponatremia) and mortality of patients with tense ascites undergoing LVP compared with alternative agents (saline or other plasma expanders). ${ }^{44}$ Although these alternative agents might be able to replace albumin infusion by the paracentesis of $<5 \mathrm{~L}$, as previously reported, ${ }^{42,45}$ we should be cautious in distinguishing that their tense ascites was not necessarily refractory ascites. The EASL guideline adds general agreement to the recommendation that these patients should still be treated with albumin because of concerns on the use of alternative plasma expanders. ${ }^{4}$ In fact, several beneficial physiological effects of albumin have been discussed in relation to its clinical effects on refractory ascites, SBP, HRS, and HE. ${ }^{46}$

LVP with $20 \%$ human albumin supplementation has further been proven to be safe in terms of circulatory function with immediate and sustained improvement of respiratory function in critically ill patients with ascites requiring mechanical ventilation. ${ }^{47}$ Although a paracentesis of around $6 \mathrm{~L}$ was reported to be uneventful without remarkable changes in the hemodynamic parameters in these patients, ${ }^{47}$ the ascites was again not always refractory. It is likely that the occurrence and grade of pathophysiological changes after LVP are also dependent upon various patient factors including sex, height, weight, muscle mass, and renal function. ${ }^{43}$ Therefore, we should be cautious with regard to the volume of ascitic fluid removed and the supplementary infusion in the LVP, evaluating the condition of each patient carefully. A risky underfilling state inducing $\mathrm{HE}$ or renal failure should be avoided in any case. 


\section{Modification of LVP}

\section{Indwelling peritoneal catheter}

Patients with refractory ascites often need emergent paracentesis, despite bimonthly LVP and maximal dosing of diuretics. ${ }^{48}$ Repeated LVP has an infrequent but potential risk of life-threatening puncture complications and also a possibility of PICD and subsequent renal failure. Reinglas et $\mathrm{al}^{48}$ evaluated whether a tunneled indwelling peritoneal Pleur $\mathrm{X}^{\mathrm{TM}}$ catheter carries the potential for reducing these risks and improving the QOL of patients. The tunneled catheters are known for their lower risk of infection over non-tunneled catheters. ${ }^{48}$ In this method, most patients had $2 \mathrm{~L}$ drained thrice a week with a range of $2 \mathrm{~L}$ per week to $1 \mathrm{~L}$ per day. The drain patency of the indwelling catheter was maintained in $90 \%$ of patients with a median duration of 117.5 days. ${ }^{48}$ Microorganisms supposedly related to SBP were detected from a catheter source in $38 \%$ of patients, all of which were treated successfully with antibiotics. ${ }^{48}$ The median time for this infection was reported to be 105 days. ${ }^{48}$ The PleurX drain system may thus help cirrhotic patients in managing refractory ascites at home under strict supervision of local physicians similarly with recurrent pleural effusions and malignant ascites. Van Thiel et $\mathrm{al}^{49}$ reported that if the procedure is limited to $72 \mathrm{~h}$, no cases of ascitic fluid contamination/infection will occur. However, the prophylactic use of antibiotics seems necessary for patients with advanced cirrhosis with hyperbilirubinemia to prevent risky infection. Kathpalia et al ${ }^{50}$ reported that patients with end-stage liver cirrhosis undergoing the procedure had a $10 \%$ risk of bacterial peritonitis within $72 \mathrm{~h}$, leading to $50 \%$ mortality at 5 months. In this study,${ }^{50}$ higher serum total bilirubin levels and a long time from admission to drain placement were associated with decreased survival in patients who developed peritonitis. The authors considered that the higher rate of SBP may be related to the higher percentage of alcoholic cirrhosis, as drinking alcohol is known to induce gut barrier dysfunction and endotoxemia. Martin et a $\mathrm{l}^{51}$ recently reported that largevolume peritoneal drainage with an indwelling peritoneal catheter and concomitant albumin infusion for a maximum of $72 \mathrm{~h}$ is safe and effective for patients with tense ascites. They further considered that the slow gravity-dependent removal of ascitic fluid along with albumin infusion could have a further beneficial role in preventing renal dysfunction and HRS compared with the rapid LVP. ${ }^{51}$

Although the permissive duration of indwelling catheterization has not been determined yet, we should keep in mind that the longer the indwelling catheterization, the higher the risk for infections. It is important to balance the high risk of infection against the potential preservation of renal function and improvement of the QOL. ${ }^{48}$

\section{Cell-free and concentrated ascites reinfusion therapy}

The reinfusion of concentrated ascites, now termed as cellfree and concentrated ascites reinfusion therapy (CART), was developed as a modification of LVP in Japan. It has been proven to be as safe and effective as LVP with albumin infusion. ${ }^{52}$ This therapy aims to maintain serum albumin levels by filtrating and concentrating the removed ascitic fluid, followed by intravenous reinfusion of the collected proteins. ${ }^{53}$ Kozaki et $a l^{54}$ retrospectively evaluated the effectiveness and adverse events in 24 CART processes in 11 patients with decompensated liver cirrhosis. The amounts of collected and concentrated ascites were $4492 \pm 2223 \mathrm{~mL}$ (mean \pm SD) and $270 \pm 270 \mathrm{~mL}$, respectively, with a concentration ratio of $22.4 \pm 15.3$ times. They reported a transient fever in one patient, which immediately subsided with the use of nonsteroidal anti-inflammatory drugs ${ }^{54}$ The benefit of CART in reducing albumin use has been emphasized, although the cost of instruments for CART, higher than that of albumin solution, is considered as a drawback. ${ }^{1,55}$ The cost-benefit problem should be definitely resolved for the further application of CART worldwide. Yamada et a ${ }^{56}$ have recently developed a drop-type CART with adjustable concentrator (DC-CART) that uses a drop-type filtration mechanism. The DC-CART requires no specialized equipment except for a simple pump and pressure monitor. ${ }^{56}$ It could concentrate large amounts of ascitic fluid (from a median weight of 4900 to $695 \mathrm{~g}$; median concentration ratio: 7.4 ) in 98 patients with refractory ascites including 14 cirrhotic patients.

\section{Peritoneal-urinary drainage (alfapump ${ }^{\circledR}$ system)}

The automated low-flow ascites pump (alfapump), a subcutaneously implanted battery-operated device, pumps ascitic fluid from the peritoneal cavity into the urinary bladder ${ }^{57}$ enabling a continuous low-volume paracentesis. ${ }^{58}$ The daily amount of ascitic fluid to be removed is adjusted based on the patient's requirements, which is controlled by the wireless programming system. ${ }^{58}$ It is activated every $10-15 \mathrm{~min}$ and moves $3-30 \mathrm{~mL}$ of ascitic fluid into the bladder in each cycle and is inactivated during the night while the patient is asleep. ${ }^{58}$ In a recent RCT in seven institutions, ${ }^{59}$ the alfapump system was proven to be effective in reducing the need for paracentesis ( $>50 \%$ of patients over 6 months) and improving the health-related QOL (especially in the first 3 months), compared with the standard LVP treatment. The system was 
associated with improvements in the nutritional status of patients assessed by the body mass index (BMI), hand grip strength, triceps skinfold thickness, and midarm muscle circumference, compared with the standard LVP treatment. The authors speculated that this nutritional benefit may involve attenuation of the increased resting energy expenditure. ${ }^{60,61}$

On the other hand, Sola et $a^{58}$ pointed out that the system was associated with enhancement of endogenous vasoconstrictor systems and impairment of renal function. They believed that the continuous ascitic fluid drainage by the alfapump may impair the effective arterial blood volume, mimicking PICD after LVP. They proposed a study focusing on the potential benefit of albumin infusion in counteracting these adverse effects. ${ }^{58}$ There are still a number of adverse events related to the procedure and the device, such as wound dehiscence, wound infection, abdominal wall hematoma, kinking of the bladder catheter, and pump pocket infection, which often require surgical reinterventions. ${ }^{58,62}$ Due to frequent and serious comorbidities, careful patient selection and postoperative monitoring are required. ${ }^{62}$ In summary, this system is considered useful in improving QOL and is a promising alternative for patients treated with LVP. However, we should carefully weigh the benefit against its invasiveness and frequent complications.

\section{PVS}

PVS (LeVeen shunt and its variant Denver shunt) was designed to palliate ascites by reinfusing ascitic fluid into the systemic circulation. PVS was reported to improve GFR and provide palliation in $83 \%$ of patients with intractable ascites awaiting LT. ${ }^{63}$ Control of ascites was achieved sooner after PVS than after TIPS, but long-term efficacy favored TIPS. ${ }^{64}$ PVS prolonged the time to the recurrence of ascites compared with diuretic treatment ${ }^{65}$ and LVP with albumin infusion. ${ }^{66}$ However, the poor long-term patency, excessive complications (disseminated intravascular coagulation [DIC], cardiac failure, sepsis, etc.), and no survival advantage compared with medical therapy have restricted its indication only to patients for whom other treatment modalities are impossible. ${ }^{1,5}$ Taken together, PVS has been considered to have a very small role in the management of refractory ascites according to the EASL guidelines. ${ }^{4}$ However, the Denver shunt is prevailing in the actual patient care situation as it has been acknowledged to prolong relief of ascites, thereby improving the QOL. A review of 62 patients between 2003 and $2014^{67}$ concluded that the percutaneous placement of a Denver shunt was technically feasible and effective. The postoperative complications in this study were relatively few, including shunt infection in three and shunt occlusion in four patients. ${ }^{67}$ The major concern is how to prevent serious complications and to preserve long-term patency. The two major risky complications occurring immediately after the shunting are DIC and infections related to the infusion of ascitic fluid into the circulation. Most ascitic fluid should be removed, and antibiotics should be prophylactically given. ${ }^{67}$ The valve must be pumped daily to prevent fibrous particles from adhering to the catheter and causing obstruction. ${ }^{68}$ It is very important to ensure that the patient and caregiver understand how to pump the shunt properly before discharge. ${ }^{68}$

\section{TIPS}

TIPS may be indicated for patients who are refractory to paracentesis or who need very frequent LVP. ${ }^{3}$ Despite remarkable technical developments, the risk of the procedure must always be balanced with the benefit of the patient surviving long enough to receive LT. ${ }^{69}$ The decision to perform or not perform TIPS should be reached carefully, considering the contraindications and evaluating the clinical conditions of the patient. The absolute contraindications include congestive heart failure, severe tricuspid regurgitation, severe pulmonary hypertension, and advanced liver failure (Table 2$).{ }^{69}$ The relative contraindications include portal venous obstruction, large hepatic tumors, extensive polycystic liver disease, severe coagulopathy, recurrent or persistent $\mathrm{HE}$, and advanced age (Table 2). ${ }^{69,70}$

Several meta-analyses based on RCTs have revealed that TIPS is superior to LVP in controlling ascites, although it causes HE more frequently. ${ }^{71-74}$ In contrast to the previous meta-analyses ${ }^{71-74}$ concluding that TIPS does not improve survival compared with LVP, recent meta-analyses ${ }^{75,76}$ including newer RCTs have reported that TIPS significantly improves transplant-free survival. The early studies with uncovered stents led to a high rate of shunt dysfunction, which was the main drawback of this treatment. ${ }^{61}$ The development of polytetrafluoroethylene (PTFE)-covered stents was a major progress, resulting in a substantial decrease in shunt dysfunction and an improved clinical outcome. ${ }^{61,77,78}$ The covered stent offers better symptomatic control and overall survival, especially in patients with an MELD score of $<16$ at the baseline. ${ }^{76,79}$ Bureau et $\mathrm{l}^{61}$ further reported that cirrhotic patients with recurrent ascites who received covered stents showed a higher rate of 1-year transplantation-free survival (93\%), compared with those treated with repeated LVP with albumin infusion (52\%). The 1-year transplantation-free survival rate in their TIPS group was also higher than those in the studies using bare metal stents $(77 \%$ and $80 \%$ in the 
two more recent studies). ${ }^{80,81}$ Retrospective, matched cohort analysis $^{82}$ has further revealed that TIPS placement is associated with improved renal function in cirrhotic patients with baseline estimated GFRs $<60 \mathrm{~mL} / \mathrm{min} / 1.73 \mathrm{~m}^{2}$ compared with repeated LVP.

In principle, large-diameter TIPS poses the risk of inducing severe HE, although a very small shunt is not effective for portal decompression. A 10-mm PTFE-covered stent results in better control of refractory ascites in patients with cirrhosis, compared with an 8-mm stent, without increasing the incidence of HE. ${ }^{83}$ Surprisingly, the use of covered stents has been associated with a lower incidence of post-TIPS HE compared with bare metal stents in some studies. ${ }^{83-85}$ While a high portosystemic pressure gradient (PSG) after TIPS might cause persistence of ascites, ${ }^{70}$ excessive reduction of the PSG ( $<8 \mathrm{mmHg})$ along with severe liver dysfunction is associated with an increased risk of mortality. ${ }^{86,87}$ Even the PTFE-covered stents passively expand to their maximal diameter of $10 \mathrm{~mm} 6$ weeks after TIPS insertion and cannot be dilated later depending on the patients' needs. ${ }^{87}$ In fact, the effective target reduction of PSG is unknown and may differ in each patient. ${ }^{88}$ Farsad et al ${ }^{88}$ described a technique for primary TIPS restriction using the deployment of a self-expanding PTFE-lined stent-graft within the balloonexpandable stent. With this method, a small shunt can be created initially to assess patient tolerance. ${ }^{88}$ The shunt can be increased later by stent-graft balloon dilation, if there is insufficient shunting and the patient is free from refractory HE. ${ }^{88}$ The development of an ideal stent-graft, in which the grade of shunting is later adequately adjustable to the patients' state, is still most preferable.

TIPS ameliorates portal hypertension and its complications, but it may deteriorate liver function in certain cases. It has been shown recently that early liver failure (ELF) developed in $16.8 \%$ of patients with refractory ascites receiving TIPS, even in those with an MELD score $<12 .{ }^{87,89}$ Luca et al pointed out that ELF occurred in patients with an MELD score of 11 or 12 , who showed decreased hemoglobin level and platelet count. In patients with higher MELD scores, a serum total bilirubin level over $51.3 \mu \mathrm{mol} / \mathrm{L}$ and a platelet count $<7.5 \times 10^{9} / \mathrm{L}$ have been considered as the most important determinants of 1 -year survival. ${ }^{90}$ The pathogenesis of liver failure is unknown, but the predominating hypothesis attributes this to the decreased portal venous perfusion of the liver. ${ }^{87}$ If there is a progressive deterioration of liver failure after TIPS placement, reduction or occlusion of the TIPS or LT should be indicated. ${ }^{89}$ Recent studies ${ }^{87,91-94}$ have shown that the markers of BT and systemic inflammation, such as endotoxin, soluble tumor necrosis factor (TNF) receptor, and C-X-C motif chemokine (CXCL) 11 and CXCL9 levels, decrease as early as 2 weeks after TIPS placement. The elevation of these markers was additionally reported to predict the poor prognosis of patients receiving TIPS. ${ }^{87,92-94}$ The inflammatory response is also the cardinal factor associated with the development of acute-on-chronic liver failure and short-term mortality in patients with decompensated cirrhosis. ${ }^{87,95}$ An adequate selection of patients appears to be the only method to effectively avoid post-TIPS HE and fatal ELF. ${ }^{87}$ In patients with refractory ascites, the serum total bilirubin, platelet count, and the above-mentioned biomarkers evaluating systemic inflammation may be useful for TIPS insertion candidate selection. However, the beneficial effect of TIPS on patient survival is diminished beyond 1 year, ${ }^{96}$ which might be related to the unfavorable long-lasting cardiac overload. ${ }^{87,97}$ Thus, TIPS should be considered as a bridging therapy for LT in refractory ascites. ${ }^{87}$

\section{Experimental treatments Diuretics with salt ingestion}

Following favorable results in patients with refractory congestive heart failure, Licata et $\mathrm{a}^{98}$ reported that the combination of intravenous high-dose furosemide $(250-1000 \mathrm{mg} / \mathrm{bid})$ and hypertonic saline solution ( $\mathrm{HSS} ; 150 \mathrm{~mL} \mathrm{H}_{2} \mathrm{O}$ with $\mathrm{NaCl}$ $1.4 \%-4.6 \%$ ) for several days is a safe and effective treatment for refractory ascites including diuretic-intractable ascites in cirrhotic patients. They noted a considerable improvement of ascites and Child-Pugh score with the high-dose furosemide+HSS compared with repeated paracentesis and a standard oral diuretic schedule. They later found significant reductions of serum levels of natriuretic peptides (ANP and brain natriuretic peptide [BNP]) and inflammatory cytokines (TNF- $\alpha$, interleukin [IL] $1 \beta$, and IL-6) in patients with refractory ascites treated with the high-dose furosemide+HSS injection compared with those treated with serial paracentesis. ${ }^{99}$ Salt ingestion therapy is quite the opposite of the traditional principles of ascites management indicating salt restriction. This treatment has never been discussed in the major clinical guidelines, although HSS is indicated in symptomatic patients with profound hyponatremia who are intolerant or unresponsive to free water restriction. ${ }^{100}$ The pathophysiological backgrounds of the responders to high-dose furosemide+HSS should be further cautiously investigated for adequate patient selection. While elevated serum BNP level is considered to reflect left ventricular myocardial dysfunction (impaired systolic function and/or diastolic relaxation), ${ }^{101-103}$ an elevated serum ANP level is 
attributable to increased atrial volume or pressure. ${ }^{101,103,104}$ The latter may reflect increased blood volume in liver cirrhosis (overflow state), ${ }^{104}$ although a study by Tuttolomondo et $\mathrm{a}^{99}$ did not concomitantly evaluate RAAS or SNS. It is presumed that high-dose furosemide+HSS may be effective for refractory ascites associated with cirrhotic cardiomyopathy and hypervolemia. Yakar et a ${ }^{105}$ further reported that oral high-dose furosemide (360-520 $\mathrm{mg}$ bid), spironolactone $(100 \mathrm{mg} /$ day $)$, and salt intake $(2.5 \mathrm{~g}$ bid $)$ were also associated with remarkable increases in diuresis, improvement of Child-Pugh and MELD scores, and reduction of hospitalization in cirrhotic patients with refractory (diuretic-resistant or diuretic-intractable) ascites. As an action mechanism, it was speculated that increased osmotic pressure due to rapid elevation of $\mathrm{NaCl}$ concentration induced volume mobilization into the vascular compartment and increased renal perfusion. ${ }^{105}$ However, the following questions remain: How does it actually affect systemic, renal, and cardiac circulation? How does it influence inflammation and the Child-Pugh score? There are no conclusive explanations for all of these beneficial effects. Before this paradoxical approach to ascites is generally approved, extensive clinical studies based on the-pathophysiology of ascites are required to determine its indications and contraindications.

\section{Antibiotics}

Hanafy et $\mathrm{al}^{106}$ reported that adding rifaximin and midodrine to diuretic therapy enhanced diuresis in refractory ascites improving systemic and renal hemodynamics. This augmented diuretic response, reduced the need for paracentesis, and even prolonged short-term survival. ${ }^{106}$ On the background of these findings, increased inflammatory cytokine induced by gut-derived endotoxins is considered to facilitate mesenteric vasodilation, enhancing the refractoriness of cirrhotic ascites. ${ }^{106}$ Rifaximin is supposed to improve splanchnic vasodilation through reduction of bacterial endotoxins in cirrhotic patients with ascites. ${ }^{106,107}$ The addition of rifaximin can help overcome the vascular insensitivity to vasoconstrictor midodrine, which is attributable to increased TNF- $\alpha$ and nitric oxide (NO). ${ }^{106}$ Further, norfloxacin suppresses the serum and ascitic levels of TNF- $\alpha$ and NO in patients recovering from SBP. ${ }^{108}$

SBP is a well-known precipitating factor for the development of type $1 \mathrm{HRS}$, and the mortality rate of patients with SBP is high. ${ }^{109}$ There is a prospective case-control study ${ }^{110}$ reporting that rifaximin decreased the SBP frequency in cirrhotic patients with refractory ascites. Although not limited to refractory ascites, norfloxacin prophylaxis reduced the incidence of SBP, delayed the development of HRS, and improved survival in cirrhotic patients with low ascites protein levels $(<15 \mathrm{~g} / \mathrm{L})$ and advanced liver failure (Child-Pugh score of $\geq 9$ points with a serum bilirubin level $\geq 51.3 \mu \mathrm{mol} / \mathrm{L}$ ) or impaired renal function. ${ }^{109,111}$ Recent meta-analyses have further suggested that rifaximin may be effective in preventing SBP in patients with cirrhosis and ascites compared with systemically absorbed antibiotics and placebo in these situations. ${ }^{112}$

\section{Unsolved problems}

As we pointed out in the "Introduction" section, the tolerable maximum doses of diuretics for the diagnosis of refractory ascites may differ among patients worldwide. We have no definite evidence on whether we can apply the diuretic doses from large Caucasian males to small Asian females. In the latter situation, most patients should be classified as having diuretic-intractable ascites and not as diuretic-resistant ascites. In fact, several authors outside Europe and America used their own criteria diagnosing refractory ascites based on the standard treatment regimen in their region (Table 1B). For further discussion, we should at least request all authors to clearly indicate their diuretic doses and to confirm that their patients really had refractory ascites. On the other side, we should reevaluate the safety concerns for the traditional dose escalation of oral diuretics in cirrhotic patients with ascites to prevent risky side effects.

In contrast to its ineffectiveness for refractory ascites, the V2 receptor antagonist tolvaptan has been recommended for cirrhotic patients with an earlier stage of ascites accumulation as a combination therapy with relatively low-dose standard diuretics. Our recent prospective observational study on this aspect ${ }^{113}$ suggests that the state of relative vascular underfilling attenuates the effect of tolvaptan. Large-dose diuretics pose a risk of evoking difficult-to-treat hyponatremia, which disrupts further continuation of drugs in cirrhotic patients with ascites. ${ }^{10}$ In general, most experts agree to discontinue diuretics temporarily in patients whose serum $\mathrm{Na}$ decreases to $<120-125 \mathrm{mmol} / \mathrm{L}$. The early addition of tolvaptan to diuretics may be effective in preventing the development of severe hyponatremia in the treatment of ascites, which warrants further evaluation. However, in order to establish a new strategy of pharmaceutical treatment, we need a large-scale prospective RCT comparing this combination therapy with the traditional stepped care diuretic treatment. A long-term RCT between these two may be significant in comparing the incidences of diuretic-intractable ascites and AKI as well as the patients' prognosis. However, the high cost of 
tolvaptan is a major barrier for its general use worldwide and for future trials.

Another important matter that remains unclear is the relationship between inflammatory changes and liver failure as well as poor prognosis in patients receiving TIPS. Structural and functional changes in the intestinal mucosa that increase the intestinal permeability of bacteria and its products have been reported in patients with liver cirrhosis. ${ }^{114}$ The characteristics of cirrhosis itself, including portal hypertension, alterations in the intestinal microbiota, inflammation, and oxidative stress can all affect the intestinal barrier function, leading to the so-called "leaky gut" and resultant BT and inflammation. ${ }^{115}$ When the deleterious effects of BT far surpass the protective effect of portal decompression on the gut barrier, TIPS insertion may turn out to be risky for the patients. The issue further implies the validity of microbiomebased therapeutics, which requires future investigation.

Finally, we summarized the evidence-based grading on the usefulness of various therapeutic approaches to refractory ascites, applying the Grading of Recommendations Assessment, Development, and Evaluation (GRADE) system (Table 3). ${ }^{109}$ We deemed that each treatment is useful when it is proven to alleviate ascites and improve QOL. Some treatment methods need future evaluation based on well-designed large clinical trials prior to being included in the management of refractory ascites.

\section{Future perspective}

It is plausible that marked development of antiviral therapy for patients with hepatitis $\mathrm{C}$ virus (HCV) may change the

Table 3 The evidence-based grading about the usefulness of various therapeutic approaches to refractory ascites applying the Grading of Recommendations Assessment, Development, and Evaluation (GRADE) system

\begin{tabular}{lll}
\hline $\begin{array}{l}\text { Therapeutic } \\
\text { approaches }\end{array}$ & Quality of evidence & $\begin{array}{l}\text { Strength of a } \\
\text { recommendation }\end{array}$ \\
\hline $\begin{array}{l}\text { Repeated LVP } \\
\text { Indwelling peritoneal }\end{array}$ & B & I \\
catheter & 2 \\
$\begin{array}{l}\text { Peritoneal-urinary } \\
\text { drainage }\end{array}$ & B & 2 \\
CART & B & \\
PVS & A & 2 \\
TIPS & A & 2 \\
\hline
\end{tabular}

Notes: The quality of evidence was graded as A (high), B (moderate), C (low), or $D$ (very low). The strength of a recommendation was indicated as either I (strong recommendation) or 2 (weak recommendation), for which benefit versus risk and cost were adequately evaluated.

Abbreviations: CART, cell-free and concentrated ascites reinfusion therapy; LVP, large-volume paracentesis; PVS, peritoneovenous shunt; TIPS, transjugular intrahepatic portosystemic shunt. prognosis of refractory ascites in the near future. In fact, clinical improvements following antiviral therapy with direct-acting antivirals (DAAs) can result in the withdrawal of patients with chronic HCV infection from the LT waiting list. ${ }^{116}$ A retrospective multicenter European study showed that the percentage of patients with refractory ascites halved from $28 \%$ at baseline to $14.1 \%$ after 24 weeks following the initiation of DAA treatment. ${ }^{16} \mathrm{~A}$ recent report has described a patient with HCV-related cirrhosis and refractory ascites, who was delisted for LT, achieving complete clinical recovery after successful sofosbuvir-based treatment. The best strategy in managing refractory ascites in HCV-related liver cirrhosis is evidently to restore liver function through the eradication of viral infection.

As expected from several findings summarized in this review, there is a possibility that gut-derived microbial products and subsequent local and systemic inflammation may affect the clinical course, refractoriness of ascites, and prognosis of cirrhotic patients. The systemic inflammatory response related to microbial translocation is the most probable precipitating factor for the development of ELF and high mortality in patients who receive TIPS. On the other hand, the gut-microbiome-orientated treatment with lactitol or rifaximin was reported to be ineffective for the prophylaxis of HE after the TIPS placement. In our view, intervention to improve gut microbiome should be started much earlier prior to the onset of refractory ascites. We may begin the management when the sign of decompensation is first noted in liver cirrhosis. Emerging evidence has suggested close associations between gut microbiome and the pathophysiology of liver cirrhosis, which seems to support our view. Wu et a ${ }^{117}$ reported a marked decrease in Lactobacillus rhamnosus and a reduction in Lactobacillus fermentus in the feces of patients with decompensated cirrhosis. Bajaj et al ${ }^{118}$ proposed the cirrhosis dysbiosis ratio (CDR), which is the ratio of beneficial autochthonous bacteria to potentially pathogenic bacteria, and reported that this ratio was negatively correlated to MELD score and the blood endotoxin level. A low CDR was also associated with death and organ failure within 30 days. As for microbiome-based therapeutics, a probiotic Lactobacillus GG was reported to decrease blood endotoxin and TNF- $\alpha$ levels. ${ }^{119} \mathrm{~A}$ probiotic combination VSL \#3 reduced arterial ammonia levels, ameliorated small intestinal bacterial overgrowth, and improved psychometric HE. ${ }^{120}$ Among antibiotics, rifaximin is known to decrease cardiac output and increase systemic vascular resistance, GFR, and natriuresis. ${ }^{107}$ It is associated with the improvement of cognitive function and endotoxemia in patients with minimal HE. ${ }^{121} \mathrm{An}$ 
effective combination of probiotics with adequate prebiotics to the nutritional therapy may improve the clinical course of cirrhotic patients. These results and assumptions further raise three important research questions: Are these therapeutic approaches beneficial to cirrhotic patients at the early stage of decompensation? Do they improve the prognosis of cirrhotic patients with ascites? When should we initiate rifaximin in the disease process of advanced cirrhosis with ascites?

\section{Conclusion}

The general therapeutic algorithm for refractory ascites is shown in Figure 1. Although there have been various challenges in exploring innovative therapeutic strategies, refractory ascites is still associated with increased morbidity and mortality in patients with liver cirrhosis. The median survival of cirrhotic patients with refractory ascites is $\sim 6$ months, ${ }^{4}$ which necessitates the consideration of LT. It is true that the best solution for refractory ascites is to eliminate hepatic failure either by LT or by causal treatment, but we should attempt to seek out the second best solution with the aim of achieving the longest possible comfortable life for patients. The selection of the most appropriate palliative therapy for individual patients, whether it be serial LVP, indwelling peritoneal catheter, peritoneal-urinary drainage, CART, TIPS, or PVS, depends on the adequate evaluation of patients, wise strategy decisions, and meticulous planning for the achievement of the best QOL. In evaluating patients, we should be able to discriminate between diuretic-intractable ascites and diuretic-resistant ascites because the former is presumably more prone to developing dilutional hyponatremia and renal

Diuretic-resistant or diuretic-intractable ascites

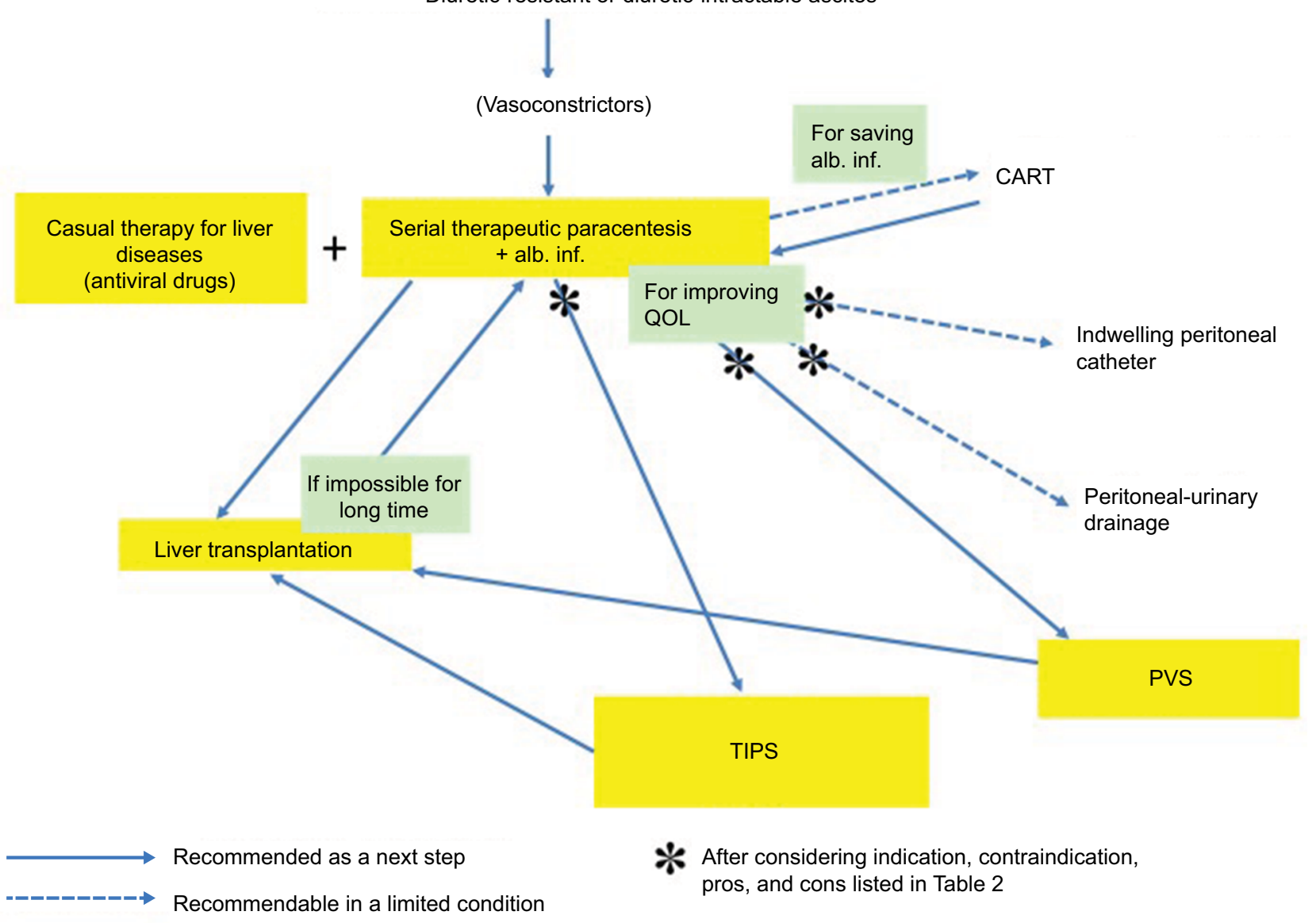

Figure I Therapeutic algorithm for refractory ascites.

Notes: Diuretic-resistant or diuretic-intractable ascites are treated by serial therapeutic paracentesis. Meanwhile, all these patients necessitate the consideration of liver transplantation. If transplantation is difficult or takes long time, the patients should be treated by paracentesis for a time being. If indicated, TIPS and PVS can be selected as bridge therapies to liver transplantation. Indwelling peritoneal catheter and peritoneal-urinary drainage are rarely selected for improving QOL of patients who are not candidates for liver transplantation or TIPS. In Japan, CART is sometimes selected to save the requirement of albumin solution after therapeutic paracentesis. Causal treatment of liver disease itself with direct-acting antivirals may dramatically improve the prognosis of patients with hepatitis $C$ virus infection.

Abbreviations: alb. inf., albumin infusion; CART, cell-free and concentrated ascites reinfusion therapy; PVS, peritoneovenous shunt; QOL, quality of life; TIPS, transjugular intrahepatic portosystemic shunt. 
dysfunction during the treatment, and may be associated with poor prognosis. ${ }^{21,29}$

In advanced cirrhosis, intestinal bacterial overgrowth predisposes patients to BT and increases the risk of SBP, together with intestinal hyperpermeability. ${ }^{122,123}$ It is well known that bacterial infections including SBP increase mortality four-fold in cirrhotic patients. ${ }^{124}$ The present review suggests that the gut-derived local and systemic inflammation limits the effects of palliative treatment for refractory ascites and is associated with high mortality risk. Although various microbiome-based therapeutics, such as probiotics, prebiotics, synbiotics, and antibiotics, have been applied for the management of $\mathrm{HE}$, the earlier therapeutic approach to gut dysbiosis may provide us with a better solution in the management of cirrhotic ascites. It should be further investigated whether any combination of probiotics, prebiotics, and antibiotics, such as rifaximin, could generally improve the clinical situation of patients after the onset of ascites.

\section{Disclosure}

Hitoshi Yoshiji has received fees for serving as a speaker and a moderator of several meetings from Otsuka Pharmaceutical Co., Ltd. The other authors report no conflicts of interest in this work.

\section{References}

1. Fukui H, Saito H, Ueno Y, et al. Evidence-based clinical practice guidelines for liver cirrhosis 2015. J Gastroenterol. 2016;51(7):629-650.

2. Arroyo V, Gines P, Gerbes AL, et al. Definition and diagnostic criteria of refractory ascites and hepatorenal syndrome in cirrhosis. International Ascites Club. Hepatology. 1996;23(1):164-176.

3. Solà E, Solé C, Ginès P. Management of uninfected and infected ascites in cirrhosis. Liver Int. 2016;36 Suppl 1:109-115.

4. European Association for the Study of the Liver. EASL clinical practice guidelines on the management of ascites, spontaneous bacterial peritonitis, and hepatorenal syndrome in cirrhosis. $J$ Hepatol. 2010;53(3):397-417.

5. Runyon BA. Management of adult patients with ascites due to cirrhosis: update 2012. AASLD. Available from: https://www.aasld. org/sites/default/files/guideline_documents/141020_Guideline_ Ascites_4UFb_2015.pdf. Accessed June 7, 2018

6. Ohki T, Sato K, Yamada T, et al. Efficacy of tolvaptan in patients with refractory ascites in a clinical setting. World J Hepatol. 2015;7(12): $1685-1693$.

7. Tahara T, Mori K, Mochizuki M, et al. Tolvaptan is effective in treating patients with refractory ascites due to cirrhosis. Biomed Rep. 2017;7(6):558-562.

8. Singh V, Dhungana SP, Singh B, et al. Midodrine in patients with cirrhosis and refractory or recurrent ascites: a randomized pilot study. $J$ Hepatol. 2012;56(2):348-354.

9. Fukui H. Gut microbiome-based therapeutics in liver cirrhosis: basic consideration for the next step. J Clin Transl Hepatol. 2017;5(3):249-260.

10. Fukui $H$. Do vasopressin V2 receptor antagonists benefit cirrhotics with refractory ascites? World J Gastroenterol. 2015;21(41):11584-11596.

11. Takaya A, Fukui H, Matsumura M, et al. Stepped care medical treatment for cirrhotic ascites: analysis of factors influencing the response to treatment. J Gastroenterol Hepatol. 1995;10(1):30-35.
12. Salerno F, Guevara M, Bernardi M, et al. Refractory ascites: pathogenesis, definition and therapy of a severe complication in patients with cirrhosis. Liver Int. 2010;30(7):937-947.

13. Singh V, Singh A, Singh B, et al. Midodrine and clonidine in patients with cirrhosis and refractory or recurrent ascites: a randomized pilot study. Am J Gastroenterol. 2013;108(4):560-567.

14. Lenz K, Buder R, Kapun L, Voglmayr M. Treatment and management of ascites and hepatorenal syndrome: an update. Therap Adv Gastroenterol. 2015;8(2):83-100.

15. Tandon P, Tsuyuki RT, Mitchell L, et al. The effect of 1 month of therapy with midodrine, octreotide-LAR and albumin in refractory ascites: a pilot study. Liver Int. 2009;29(2):169-174.

16. Lenaerts A, Codden T, Meunier JC, Henry JP, Ligny G. Effects of clonidine on diuretic response in ascitic patients with cirrhosis and activation of sympathetic nervous system. Hepatology. 2006;44(4):844-849.

17. Yang YY, Lin HC, Lee WP, et al. Association of the G-protein and $\alpha 2$-adrenergic receptor gene and plasma norepinephrine level with clonidine improvement of the effects of diuretics in patients with cirrhosis with refractory ascites: a randomised clinical trial. Gut. 2010;59(11):1545-1553.

18. Krag A, Møller S, Henriksen JH, Holstein-Rathlou NH, Larsen FS, Bendtsen F. Terlipressin improves renal function in patients with cirrhosis and ascites without hepatorenal syndrome. Hepatology. 2007;46(6):1863-1871.

19. Kalambokis GN, Pappas K, Baltayiannis G, Katsanou A, Tsianos EV. Effects of terlipressin on water excretion after oral water load test in nonazotemic cirrhotic patients with ascites without hyponatremia. Scand J Gastroenterol. 2010;45(12):1509-1515.

20. Fimiani B, Guardia DD, Puoti C, et al. The use of terlipressin in cirrhotic patients with refractory ascites and normal renal function: a multicentric study. Eur J Intern Med. 2011;22(6):587-590.

21. Sersté T, Melot C, Francoz C, et al. Deleterious effects of beta-blockers on survival in patients with cirrhosis and refractory ascites. Hepatology. 2010;52(3):1017-1022.

22. Ferrarese A, Zanetto A, Germani G, Burra P, Senzolo M. Rethinking the role of non-selective beta blockers in patients with cirrhosis and portal hypertension. World J Hepatol. 2016;8(24):1012-1018.

23. Krag A, Wiest R, Albillos A, Gluud LL. The window hypothesis: haemodynamic and non-haemodynamic effects of beta-blockers improve survival of patients with cirrhosis during a window in the disease. Gut. 2012;61(7):967-969.

24. La Mura V, Tosetti G, Primignani M, Salerno F. Use of non-selective beta blockers in cirrhosis: the evidence we need before closing (or not) the window. World J Gastroenterol. 2015;21(8):2265-2268.

25. Bossen L, Krag A, Vilstrup H, Watson H, Jepsen P. Nonselective betablockers do not affect mortality in cirrhosis patients with ascites: post hoc analysis of three randomized controlled trials with 1198 patients. Hepatology. 2016;63(6):1968-1976.

26. Onali S, Kalafateli M, Majumdar A, et al. Non-selective beta-blockers are not associated with increased mortality in cirrhotic patients with ascites. Liver Int. 2017;37(9):1334-1344.

27. Bhutta AQ, Garcia-Tsao G, Reddy KR, et al. Beta-blockers in hospitalised patients with cirrhosis and ascites: mortality and factors determining discontinuation and reinitiation. Aliment Pharmacol Ther. 2018;47(1):78-85.

28. Reiberger T, Ferlitsch A, Payer BA, et al. Non-selective betablocker therapy decreases intestinal permeability and serum levels of LBP and IL-6 in patients with cirrhosis. J Hepatol. 2013;58(5):911-921.

29. Blasco-Algora S, Masegosa-Ataz J, Alonso S, Gutiérrez ML, Fernández-Rodriguez C. Non-selective $\beta$-blockers in advanced cirrhosis: a critical review of the effects on overall survival and renal function. BMJ Open Gastroenterol. 2016;3(1):e000104.

30. Moctezuma-Velazquez C, Kalainy S, Abraldes JG. Beta-blockers in patients with advanced liver disease: has the dust settled? Liver Transpl. 2017;23(8):1058-1069.

31. Gatta A, Caregaro L, Angeli P, et al. Impaired renal water excretion in liver cirrhosis. The role of reduced distal delivery of sodium. Scand $J$ Gastroenterol. 1988;23(5):523-528. 
32. Krag A, Møller S, Pedersen EB, Henriksen JH, Holstein-Rathlou NH, Bendtsen F. Impaired free water excretion in child C cirrhosis and ascites: relations to distal tubular function and the vasopressin system. Liver Int. 2010;30(9):1364-1370.

33. Wong F, Watson H, Gerbes A, et al; Satavaptan Investigators Group. Satavaptan for the management of ascites in cirrhosis: efficacy and safety across the spectrum of ascites severity. Gut. 2012;61(1):108-116.

34. Okita K, Kawazoe S, Hasebe C, et al; ASCITES Dose-Finding Trial Group. Dose-finding trial of tolvaptan in liver cirrhosis patients with hepatic edema: a randomized, double-blind, placebo-controlled trial. Hepatol Res. 2014;44(1):83-91.

35. Sakaida I, Yanase M, Kobayashi Y, Yasutake T, Okada M, Okita K; ASCITES Clinical Pharmacology Group. The pharmacokinetics and pharmacodynamics of tolvaptan in patients with liver cirrhosis with insufficient response to conventional diuretics: a multicentre, double-blind, parallelgroup, phase III study. J Int Med Res. 2012;40(6):2381-2393.

36. Zhang X, Wang SZ, Zheng JF, et al. Clinical efficacy of tolvaptan for treatment of refractory ascites in liver cirrhosis patients. World $J$ Gastroenterol. 2014;20(32):11400-11405.

37. Akiyama S, Ikeda K, Sezaki H, et al. Therapeutic effects of short- and intermediate-term tolvaptan administration for refractory ascites in patients with advanced liver cirrhosis. Hepatol Res. 2015;45(11):1062-1070.

38. Fortune B, Cardenas A. Ascites, refractory ascites and hyponatremia in cirrhosis. Gastroenterol Rep (Oxf). 2017;5(2):104-112.

39. Pozzi M, Osculati G, Boari G, et al. Time course of circulatory and humoral effects of rapid total paracentesis in cirrhotic patients with tense, refractory ascites. Gastroenterology. 1994;106(3):709-719.

40. Luca A, Feu F, Garcia-Pagan JC, et al. Favorable effects of total paracentesis on splanchnic hemodynamics in cirrhotic patients with tense ascites. Hepatology. 1994;20(1 Pt 1):30-33.

41. Ginés P, Arroyo V, Quintero E, et al. Comparison of paracentesis and diuretics in the treatment of cirrhotics with tense ascites. Results of a randomized study. Gastroenterology. 1987;93(2):234-241.

42. Ginés A, Fernández-Esparrach G, Monescillo A, et al. Randomized trial comparing albumin, dextran 70 , and polygeline in cirrhotic patients with ascites treated by paracentesis. Gastroenterology. 1996;111(4):1002-1010.

43. Annamalai A, Wisdom L, Herada M, et al. Management of refractory ascites in cirrhosis: are we out of date? World J Hepatol. 2016;8(28):1182-1193

44. Bernardi M, Caraceni P, Navickis RJ, Wilkes MM. Albumin infusion in patients undergoing large-volume paracentesis: a meta-analysis of randomized trials. Hepatology. 2012;55(4):1172-1181.

45. Sola-Vera J, Miñana J, Ricart E, et al. Randomized trial comparing albumin and saline in the prevention of paracentesis-induced circulatory dysfunction in cirrhotic patients with ascites. Hepatology. 2003;37(5):1147-1153.

46. Garcia-Martinez R, Caraceni P, Bernardi M, Gines P, Arroyo V, Jalan R. Albumin: pathophysiologic basis of its role in the treatment of cirrhosis and its complications. Hepatology. 2013;58(5):1836-1846.

47. Phillip V, Saugel B, Ernesti C, et al. Effects of paracentesis on hemodynamic parameters and respiratory function in critically ill patients. BMC Gastroenterol. 2014;14:18.

48. Reinglas J, Amjadi K, Petrcich B, Momoli F, Shaw-Stiffel T. The palliative management of refractory cirrhotic ascites using the PleurX (C) catheter. Can J Gastroenterol Hepatol. 2016;2016:4680543.

49. Van Thiel DH, Moore CM, Garcia M, George M, Nadir A. Continuous peritoneal drainage of large-volume ascites. Dig Dis Sci. 2011;56(9):2723-2727.

50. Kathpalia P, Bhatia A, Robertazzi S, et al. Indwelling peritoneal catheters in patients with cirrhosis and refractory ascites. Intern Med J. 2015;45(10):1026-1031.

51. Martin DK, Walayat S, Jinma R, Ahmed Z, Ragunathan K, Dhillon $\mathrm{S}$. Large-volume paracentesis with indwelling peritoneal catheter and albumin infusion: a community hospital study. J Community Hosp Intern Med Perspect. 2016;6(5):32421.
52. Graziotto A, Rossaro L, Inturri P, Salvagnini M. Reinfusion of concentrated ascitic fluid versus total paracentesis. A randomized prospective trial. Dig Dis Sci. 1997;42(8):1708-1714.

53. Inoue N, Yamazaki Z, Oda T, Sugiura M, Wada T. Treatment of intractable ascites by continuous reinfusion of the sterilized, cell-free and concentrated ascitic fluid. Trans Am Soc Artif Intern Organs. 1977;23:699-702.

54. Kozaki K, IInuma M, Takagi T, et al. Cell-free and concentrated ascites reinfusion therapy for decompensated liver cirrhosis. Ther Apher Dial. 2016;20(4):376-382.

55. Zaak D, Paquet KJ, Kuhn R. Prospective study comparing human albumin vs. reinfusion of ultrafiltrate-ascitic fluid after total paracentesis in cirrhotic patients with tense ascites. Z Gastroenterol. 2001;39(1):5-10.

56. Yamada Y, Harada M, Yamaguchi A, et al. Technical performance and clinical effectiveness of drop type with adjustable concentratorcell free and concentrated ascites reinfusion therapy. Artif Organs. 2017;41(12):1135-1144

57. Stirnimann G, Banz V, Storni F, De Gottardi A. Automated low-flow ascites pump for the treatment of cirrhotic patients with refractory ascites. Therap Adv Gastroenterol. 2017;10(2):283-292.

58. Solà E, Sanchez-Cabús S, Rodriguez E, et al. Effects of alfapump ${ }^{\mathrm{TM}}$ system on kidney and circulatory function in patients with cirrhosis and refractory ascites. Liver Transpl. 2017;23(5):583-593.

59. Bureau C, Adebayo D, Chalret de Rieu M, et al. Alfapump ${ }^{\circledR}$ system vs. large volume paracentesis for refractory ascites: a multicenter randomized controlled study. J Hepatol. 2017;67(5):940-949.

60. Dasarathy J, Alkhouri N, Dasarathy S. Changes in body composition after transjugular intrahepatic portosystemic stent in cirrhosis: a critical review of literature. Liver Int. 2011;31(9):1250-1258.

61. Bureau C, Thabut D, Oberti F, et al. Transjugular intrahepatic portosystemic shunts with covered stents increase transplant-free survival of patients with cirrhosis and recurrent ascites. Gastroenterology. 2017;152(1):157-163.

62. Thomas MN, Sauter GH, Gerbes AL, et al. Automated low flow pump system for the treatment of refractory ascites: a single-center experience. Langenbecks Arch Surg. 2015;400(8):979-983.

63. Dumortier J, Pianta E, Le Derf Y, et al. Peritoneovenous shunt as a bridge to liver transplantation. Am J Transplant. 2005;5(8):1886-1892.

64. Rosemurgy AS, Zervos EE, Clark WC, et al. TIPS versus peritoneovenous shunt in the treatment of medically intractable ascites: a prospective randomized trial. Ann Surg. 2004;239(6):883-889; discussion 89-91.

65. Stanley MM, Ochi S, Lee KK, et al. Peritoneovenous shunting as compared with medical treatment in patients with alcoholic cirrhosis and massive ascites. Veterans Administration Cooperative Study on Treatment of Alcoholic Cirrhosis with Ascites. N Engl J Med. 1989;321(24):1632-1638.

66. Ginès $\mathrm{P}$, Arroyo V, Vargas V, et al. Paracentesis with intravenous infusion of albumin as compared with peritoneovenous shunting in cirrhosis with refractory ascites. N Engl J Med. 1991;325(12):829-835.

67. Piccirillo M, Rinaldi L, Leongito M, et al. Percutaneous implant of Denver peritoneo-venous shunt for treatment of refractory ascites: a single center retrospective study. Eur Rev Med Pharmacol Sci. 2017;21(16):3668-3673.

68. Martin LG. Percutaneous placement and management of the Denver shunt for portal hypertensive ascites. AJR Am J Roentgenol. 2012;199(4):W449-W453.

69. Boyer TD, Haskal ZJ; American Association for the Study of Liver Diseases. The role of transjugular intrahepatic portosystemic shunt (TIPS) in the management of portal hypertension: update 2009 Hepatology. 2010;51(1):306.

70. Rössle M. TIPS: 25 years later. J Hepatol. 2013;59(5):1081-1093.

71. Deltenre P, Mathurin P, Dharancy S, et al. Transjugular intrahepatic portosystemic shunt in refractory ascites: a meta-analysis. Liver Int. 2005;25(2):349-356.

72. Saab S, Nieto JM, Lewis SK, Runyon BA. TIPS versus paracentesis for cirrhotic patients with refractory ascites. Cochrane Database Syst Rev. 2006;(4):CD004889. 
73. Albillos A, Bañares R, Gonzalez M, Catalina MV, Molinero LM. A meta-analysis of transjugular intrahepatic portosystemic shunt versus paracentesis for refractory ascites. J Hepatol. 2005;43(6):990-996.

74. D'Amico G, Luca A, Morabito A, Miraglia R, D'Amico M. Uncovered transjugular intrahepatic portosystemic shunt for refractory ascites: a meta-analysis. Gastroenterology. 2005;129(4):1282-1293.

75. Salerno F, Cammà C, Enea M, Rössle M, Wong F. Transjugular intrahepatic portosystemic shunt for refractory ascites: a meta-analysis of individual patient data. Gastroenterology. 2007;133(3):825-834.

76. Bai M, Qi XS, Yang ZP, Yang M, Fan DM, Han GH. TIPS improves liver transplantation-free survival in cirrhotic patients with refractory ascites: an updated meta-analysis. World J Gastroenterol. 2014;20(10):2704-2714.

77. Angermayr B, Cejna M, Koenig F, et al; Vienna TIPS Study Group. Survival in patients undergoing transjugular intrahepatic portosystemic shunt: ePTFE-covered stentgrafts versus bare stents. Hepatology. 2003;38(4):1043-1050.

78. Perarnau JM, Le Gouge A, Nicolas C, et al. Covered vs. uncovered stents for transjugular intrahepatic portosystemic shunt: a randomized controlled trial. J Hepatol. 2014;60(5):962-968.

79. Maleux G, Perez-Gutierrez NA, Evrard S, et al. Covered stents are better than uncovered stents for transjugular intrahepatic portosystemic shunts in cirrhotic patients with refractory ascites: a retrospective cohort study. Acta Gastroenterol Belg. 2010;73(3):336-341.

80. Salerno F, Merli M, Riggio O, et al. Randomized controlled study of TIPS versus paracentesis plus albumin in cirrhosis with severe ascites. Hepatology. 2004;40(3):629-635.

81. Narahara Y, Kanazawa H, Fukuda T, et al. Transjugular intrahepatic portosystemic shunt versus paracentesis plus albumin in patients with refractory ascites who have good hepatic and renal function: a prospective randomized trial. $J$ Gastroenterol. 2011;46(1):78-85.

82. Allegretti AS, Ortiz G, Cui J, et al. Changes in kidney function after transjugular intrahepatic portosystemic shunts versus large-volume paracentesis in cirrhosis: a matched cohort analysis. Am J Kidney Dis. 2016;68(3):381-391.

83. Miraglia R, Maruzzelli L, Tuzzolino F, Petridis I, D’Amico M, Luca A. Transjugular intrahepatic portosystemic shunts in patients with cirrhosis with refractory ascites: comparison of clinical outcomes by using 8- and 10-mm PTFE-covered stents. Radiology. 2017;284(1):281-288.

84. Bureau C, Garcia-Pagan JC, Otal P, et al. Improved clinical outcome using polytetrafluoroethylene-coated stents for TIPS: results of a randomized study. Gastroenterology. 2004;126(2):469-475.

85. Bureau C, Garcia Pagan JC, Layrargues GP, et al. Patency of stents covered with polytetrafluoroethylene in patients treated by transjugular intrahepatic portosystemic shunts: long-term results of a randomized multicentre study. Liver Int. 2007;27(6):742-747.

86. Harrod-Kim P, Saad WE, Waldman D. Predictors of early mortality after transjugular intrahepatic portosystemic shunt creation for the treatment of refractory ascites. J Vasc Interv Radiol. 2006;17(10):1605-1610.

87. Trebicka J. Emergency TIPS in a child-pugh B patient: when does the window of opportunity open and close? J Hepatol. 2017;66(2):442-450.

88. Farsad K, Kolbeck KJ, Keller FS, Barton RE, Kaufman JA. Primary creation of an externally constrained TIPS: a technique to control reduction of the portosystemic gradient. AJR Am J Roentgenol. 2015;204(4):868-871.

89. Luca A, Miraglia R, Maruzzelli L, D’Amico M, Tuzzolino F. Early liver failure after transjugular intrahepatic portosystemic shunt in patients with cirrhosis with model for end-stage liver disease score of 12 or less: incidence, outcome, and prognostic factors. Radiology. 2016;280(2):622-629.

90. Bureau C, Métivier S, D'Amico M, et al. Serum bilirubin and platelet count: a simple predictive model for survival in patients with refractory ascites treated by TIPS. J Hepatol. 2011;54(5):901-907.

91. Trebicka J, Krag A, Gansweid S, et al. Endotoxin and tumor necrosis factor-receptor levels in portal and hepatic vein of patients with alcoholic liver cirrhosis receiving elective transjugular intrahepatic portosystemic shunt. Eur J Gastroenterol Hepatol. 2011;23(12):1218-1225.
92. Trebicka J, Krag A, Gansweid S, et al. Soluble TNF-alpha-receptors I are prognostic markers in TIPS-treated patients with cirrhosis and portal hypertension. PLoS One. 2013;8(12):e83341.

93. Berres ML, Asmacher S, Lehmann J, et al. CXCL9 is a prognostic marker in patients with liver cirrhosis receiving transjugular intrahepatic portosystemic shunt. $J$ Hepatol. 2015;62(2):332-339.

94. Berres ML, Lehmann J, Jansen C, et al. Chemokine (C-X-C motif) ligand 11 levels predict survival in cirrhotic patients with transjugular intrahepatic portosystemic shunt. Liver Int. 2016;36(3):386-394.

95. Moreau R, Jalan R, Gines P, et al. Acute-on-chronic liver failure is a distinct syndrome that develops in patients with acute decompensation of cirrhosis. Gastroenterology. 2013;144(7):1426-1437, 1437.e1-9.

96. Gaba RC, Parvinian A, Casadaban LC, et al. Survival benefit of TIPS versus serial paracentesis in patients with refractory ascites: a single institution case-control propensity score analysis. Clin Radiol. 2015;70(5): e51-e57.

97. Wannhoff A, Hippchen T, Weiss CS, et al. Cardiac volume overload and pulmonary hypertension in long-term follow-up of patients with a transjugular intrahepatic portosystemic shunt. Aliment Pharmacol Ther. 2016;43(9):955-965.

98. Licata G, Tuttolomondo A, Licata A, et al. Clinical trial: high-dose furosemide plus small-volume hypertonic saline solutions vs. repeated paracentesis as treatment of refractory ascites. Aliment Pharmacol Ther. 2009;30(3):227-235.

99. Tuttolomondo A, Di Raimondo D, Bellia C, et al. Immune-inflammatory and metabolic effects of high dose furosemide plus hypertonic saline solution (HSS) treatment in cirrhotic subjects with refractory ascites. PLoS One. 2016;11(12):e0165443.

100. John S, Thuluvath PJ. Hyponatremia in cirrhosis: pathophysiology and management. World J Gastroenterol. 2015;21(11):3197-3205.

101. Wong F, Siu S, Liu P, Blendis LM. Brain natriuretic peptide: is it a predictor of cardiomyopathy in cirrhosis? Clin Sci (Lond). 2001;101(6):621-628

102. Henriksen JH, Gøtze JP, Fuglsang S, Christensen E, Bendtsen F, Møller S. Increased circulating pro-brain natriuretic peptide (proBNP) and brain natriuretic peptide (BNP) in patients with cirrhosis: relation to cardiovascular dysfunction and severity of disease. Gut. 2003;52(10):1511-1517.

103. Figueiredo A, Romero-Bermejo F, Perdigoto R, Marcelino P. The endorgan impairment in liver cirrhosis: appointments for critical care. Crit Care Res Pract. 2012;2012:539412.

104. Rector WG Jr, Adair O, Hossack KF, Rainguet S. Atrial volume in cirrhosis: relationship to blood volume and plasma concentration of atrial natriuretic factor. Gastroenterology. 1990;99(3):766-770.

105. Yakar T, Demir M, Dogan O, Parlakgumus A, Ozer B, Serin E. High dose oral furosemide with salt ingestion in the treatment of refractory ascites of liver cirrhosis. Clin Invest Med. 2016;39(6):27502.

106. Hanafy AS, Hassaneen AM. Rifaximin and midodrine improve clinical outcome in refractory ascites including renal function, weight loss, and short-term survival. Eur J Gastroenterol Hepatol. 2016;28(12):1455-1461.

107. Kalambokis GN, Mouzaki A, Rodi M, et al. Rifaximin improves systemic hemodynamics and renal function in patients with alcohol-related cirrhosis and ascites. Clin Gastroenterol Hepatol. 2012;10(7):815-818.

108. Zapater P, Caño R, Llanos L, et al. Norfloxacin modulates the inflammatory response and directly affects neutrophils in patients with decompensated cirrhosis. Gastroenterology. 2009;137(5):1669-1679.e1.

109. Fukui H. Endotoxin and other microbial translocation markers in the blood: a clue to understand leaky gut syndrome. Cell Mol Med. 2016;2:3.

110. Dănulescu RM, Ciobică A, Stanciu C, Trifan A. The role of rifaximine in the prevention of the spontaneous bacterial peritonitis. Rev Med Chir Soc Med Nat Iasi. 2013;117(2):315-320.

111. Fernández J, Navasa M, Planas R, et al. Primary prophylaxis of spontaneous bacterial peritonitis delays hepatorenal syndrome and improves survival in cirrhosis. Gastroenterology. 2007;133(3):818-824. 
112. Goel A, Rahim U, Nguyen LH, Stave C, Nguyen MH. Systematic review with meta-analysis: rifaximin for the prophylaxis of spontaneous bacterial peritonitis. Aliment Pharmacol Ther. 2017;46(11-12):1029-1036.

113. Kawaratani H, Fukui H, Moriya K, et al. Predictive parameter of tolvaptan effectiveness in cirrhotic ascites. Hepatol Res. 2017;47(9): 854-861.

114. Bellot P, Francés R, Such J. Pathological bacterial translocation in cirrhosis: pathophysiology, diagnosis and clinical implications. Liver Int. 2013;33(1):31-39.

115. Pijls KE, Jonkers DM, Elamin EE, Masclee AA, Koek GH. Intestinal epithelial barrier function in liver cirrhosis: an extensive review of the literature. Liver Int. 2013;33(10):1457-1469.

116. van der Meer AJ, Berenguer M. Reversion of disease manifestations after HCV eradication. J Hepatol. 2016;65(1 Suppl):S95-S108.

117. Wu ZW, Lu HF, Wu J, et al. Assessment of the fecal Lactobacilli population in patients with hepatitis B virus-related decompensated cirrhosis and hepatitis B cirrhosis treated with liver transplant. Microb Ecol. 2012;63(4):929-937.

118. Bajaj JS, Heuman DM, Hylemon PB, et al. Altered profile of human gut microbiome is associated with cirrhosis and its complications. $J$ Hepatol. 2014;60(5):940-947.
119. Bajaj JS, Heuman DM, Hylemon PB, et al. Randomised clinical trial: Lactobacillus GG modulates gut microbiome, metabolome and endotoxemia in patients with cirrhosis. Aliment Pharmacol Ther. 2014;39(10):1113-1125.

120. Lunia MK, Sharma BC, Sharma P, Sachdeva S, Srivastava S. Probiotics prevent hepatic encephalopathy in patients with cirrhosis: a randomized controlled trial. Clin Gastroenterol Hepatol. 2014;12(6):1003-1008.e1.

121. Bajaj JS, Heuman DM, Sanyal AJ, et al. Modulation of the metabiome by rifaximin in patients with cirrhosis and minimal hepatic encephalopathy. PLoS One. 2013;8(4):e60042.

122. Aldersley MA, Howdle PD. Intestinal permeability and liver disease. Eur J Gastroenterol Hepatol. 1999;11(4):401-403.

123. Thalheimer U, Triantos CK, Samonakis DN, Patch D, Burroughs AK. Infection, coagulation, and variceal bleeding in cirrhosis. Gut 2005;54(4):556-563.

124. Arvaniti V, D’Amico G, Fede G, et al. Infections in patients with cirrhosis increase mortality four-fold and should be used in determining prognosis. Gastroenterology. 2010;139(4):1246-1256, 1256.e1-5.

125. Taki Y, Kanazawa H, Narahara Y, et al. Predictive factors for improvement of ascites after transjugular intrahepatic portosystemic shunt in patients with refractory ascites. Hepatol Res. 2014;44(8):871-877.
Hepatic Medicine: Evidence and Research

\section{Publish your work in this journal}

Hepatic Medicine: Evidence and Research is an international, peerreviewed, open access journal covering all aspects of adult and pediatric hepatology in the clinic and laboratory including the following topics: Pathology, pathophysiology of hepatic disease; Investigation and treatment of hepatic disease; Pharmacology of drugs used for the treatment

\section{Dovepress}

of hepatic disease. Issues of patient safety and quality of care will also be considered. The manuscript management system is completely online and includes a very quick and fair peer-review system, which is all easy to use. Visit http://www.dovepress.com/testimonials.php to read real quotes from published authors. 